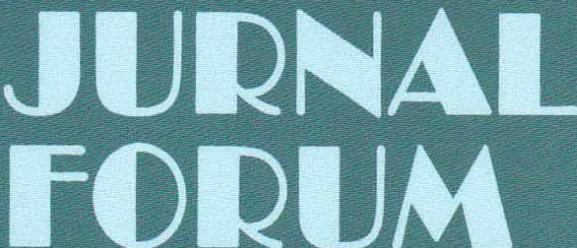

Volume 7 - Nomor 1

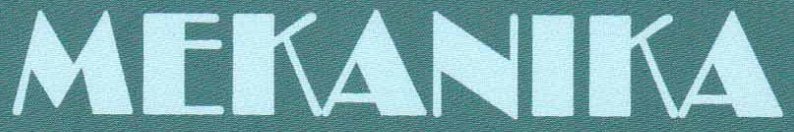

Mei 2018

ISSN : 2356-1491

PENGARUH FLY ASH DENGAN PENAMBAHAN CACAHAN KARET, SILICA FUME DAN SUPERPLASTICIZER TERHADAP BETON

TRI YUHANAH; TOMMY IDUWIN; BUDI WICAKSONO

PERILAKU STRUKTUR TOWER TRANSMISI TIPE SUSPENSION TERHADAP BEBAN ANGIN MUHAMMAD SOFYAN; DICKI DIAN PURNAMA; ABDUL ROKHMAN

IDENTIFIKASI PENYEBAB KECELAKAAN KERJA PADA PROYEK KONSTRUKSI BANGUNAN GEDUNG TINGGI

RETNA KRISTIANA; SLAMET

STUDI SIFAT MEKANIS TANAH MERAH DENGAN PENGUJIAN TRIAKSIAL REFFANDA KURNIAWAN RUSTAM

ANALISIS PENGARUH BESAR BUTIRAN AGREGAT KASAR TERHADAP KUAT TEKAN BETON NORMAL IKA SULIANTI; AMIRUDDIN; RIO SHAPUTRA; DARYOKO

ANALISIS BANJIR DAN TINGGI MUKA AIR PADA RUAS SUNGAI CILIWUNG STA 7+646 S/D STA $15+049$

IKA SARI DAMAYANTHI SEBAYANG; MELIANA PARLINA

ANALISIS KELAYAKAN PERENCANAAN PEMBANGUNAN JALAN PENGHUBUNG (MISSING LINK) ANTARA DESA SIKUR SAMPAI DESA PAOKMOTONG KABUPATEN LOMBOK TIMUR

DESSY ANGGA AFRIANTI; SIGIT IRFANSYAH; MEYRISSA PUTRI DEWANDARI 


\title{
ANALISIS BANJIR DAN TINGGI MUKA AIR PADA RUAS SUNGAI CILIWUNG STA 7+646 s/d STA 15+049
}

\author{
IKA SARI DAMAYANTHI SEBAYANG \\ Jurusan Teknik Sipil, Fakultas Teknik, Universitas Mercu Buana \\ E-mail: ikasari.damayanthi@mercubuana.ac.id \\ MELIANA PARLINA \\ Jurusan Teknik Sipil, Fakultas Teknik, Universitas Mercu Buana
}

\begin{abstract}
Abstrak
Permasalahan banjir di DKI Jakarta sudah dianggap biasa karena hampir setiap tahunnya dapat melanda Kota Jakarta terutama pada saat musim hujan. Di DKI Jakarta sendiri terdapat beberapa sungai, salah satunya yaitu Sungai Ciliwung yang merupakan sungai paling berpengaruh di DKI Jakarta yang kerap menimbulkan banjir tiap tahunnya. Tujuan dari penelitian ini untuk mengetahui lokasi luapan permukaan sungai/banjir yang terjadi di ruas-ruas sepanjang Sungai Ciliwung STA 7+646 s/d STA $15+049$. Pengolahan data dimulai dengan perhitungan curah hujan rata-rata, analisis frekuensi, kemudian distribusi hujan jam-jaman. Metode perhitungan debit banjir menggunakan hidrograf satuan sintetik Nakayasu dan Gama I. Data curah hujan menggunakan 2 stasiun pengamatan hujan selama 3 tahun (2014-2016). Pada analisis frekuensi digunakan distribusi Gumbel berdasrkan hasil uji kesesuaian data Smirnov- Kolmogorov dan Chi-Square. Hasil perhitungan debit puncak banjir rancangan dengan HSS Nakayasu pada periode ulang $Q 5=687,80 \mathrm{m3} / \mathrm{dt}, Q 10=743,21 \mathrm{m3} / \mathrm{dt}, Q 20=796,36 \mathrm{m3} / \mathrm{dt}, Q 50=865,15 \mathrm{m3} / \mathrm{dt}, Q 100=916,71$ $m 3 / d t$, sedangkan debit puncak banjir rancangan dengan HSS Gama I pada periode ulang Q5 = 347,03 $\mathrm{m3} / \mathrm{dt}, Q 10=372,12 \mathrm{m3} / \mathrm{dt}, Q 20=396,20 \mathrm{m3} / \mathrm{dt}, Q 50=427,36 \mathrm{m3} / \mathrm{dt}, Q 100=450,71 \mathrm{~m} 3 / \mathrm{dt}$. Nilai debit banjir rancangan yang mendekati nilai debit terukur adalah HSS Nakayasu. Langkah dilanjutkan menggunakan software HEC-RAS 4.1.0 untuk mengetahui kapasitas tampung sungai dengan menggunakan debit Nakayasu. Setelah dianalisis menggunakan perangkat lunak, Sebagian besar stationing Sungai Ciliwung pada STA 7+646 s/d STA 15+049 tidak dapat menampung debit rencana pada periode ulang 20 tahun, oleh karenanya perlu adanya perbaikan sungai berupa normalisasi sungai dan peninggian tanggul.
\end{abstract}

Kata kunci : Debit banjir, HSS Nakayasu, HSS Gama I, Tinggi muka air banjir, HEC- RAS 4.1.0

\begin{abstract}
The problem of flooding in DKI Jakarta is considered normal because almost every year can hit the city of Jakarta especially during the rainy season. In DKI Jakarta itself there are several rivers, one of which is Ciliwung River which is the most influential river in DKI Jakarta which often cause flood every year. The purpose of this research is to know the location of flood / river flood that occurs in the segments along Ciliwung River STA $7+646 s / d$ STA $15+049$. Data processing begins with the calculation of average rainfall, frequency analysis, and then hour-time rain distribution. Method of calculation of flood discharge using the synthetic unit of Nakayasu and Gama I synthetic data. Rainfall data using 2 observation stations for 3 years rain (2014-2016). In the frequency analysis used Gumbel distribution berdasrkan test results suitability data Smirnov-Kolmogorov and Chi-Square. The result of flood peak discharge design with HSS Nakayasu on return period $Q 5=687,80 \mathrm{~m} 3 / \mathrm{dt}, Q 10=743,21 \mathrm{m3} / \mathrm{dt}, Q 20=796,36 \mathrm{~m} 3 / \mathrm{s}, Q 50=865,15$ $m 3 / d t, Q 100=916,71 \mathrm{m3} / \mathrm{s}$, while flood peak discharge design with HSS Gama I on return period Q5 = $347,03 \mathrm{m3} / \mathrm{s}, Q 10=372,12 \mathrm{m3} / \mathrm{s}, Q 20=396,20 \mathrm{m3} / \mathrm{s}, Q 50=427,36 \mathrm{m3} / \mathrm{s}, Q 100=450,71 \mathrm{~m} 3 / \mathrm{s} . \mathrm{The}$ design flood discharge value approaching the measured debit value is HSS Nakayasu. Steps continued using HEC-RAS 4.1.0 software to determine the capacity of river catchment by using Nakayasu discharge. After analyzing using the software, most stationing of the Ciliwung River at STA $7+646$ to STA $15+049$ can not accommodate the planned discharge during the 20th anniversary period, hence the need for river improvements in the form of river normalization and elevation of dikes.
\end{abstract}

Keywords: Flood discharge, HSS Nakayasu, HSS Gama I, Flood water level, HEC-RAS 4.1.0 


\section{Latar Belakang}

Menurut Badan Nasional Penanggulangan Bencana (BNPB), terdapat 6000 lebih kasus bencana banjir yang terjadi di Indonesia sejak tahun 1815 hingga Februari 2017. Di DKI Jakarta sendiri terdapat beberapa sungai, salah satunya yaitu Sungai Ciliwung yang merupakan sungai paling berpengaruh di DKI Jakarta yang kerap menimbulkan banjir tiap tahunnya.

Salah satu sungai yang seringkali meluap adalah Sungai Ciliwung. Sungai Ciliwung bermata air di Telaga Warna Puncak Pas di Gunung Pangrango, bermuara di Banjir Kanal Barat dan Drainase Gunung Sahari (Pintu Air Kapitol). Panjang sungai dari hulu sampai dengan Pintu Air Manggarai $109.71 \mathrm{~km}$, dan daerah pengaliran seluas $330.224 \mathrm{~km}^{2}$. Sungai Ciliwung merupakan sungai besar, pada saat musim penghujan kelebihan air dan dimusim kemarau kekurangan air. Pemanfaatan air pada Sungai Ciliwung ini belum dilakukan secara optimal, sehingga pada musim penghujan di beberapa lokasi sering tergenang/banjir. Oleh karena itu perlu diadakan kajian mengenai bencana banjir yang terjadi, pada penelitian ini akan dilakukan peninjauan khususnya di ruas Sungai Ciliwung STA $7+646$ s/d STA $15+049$.

Maksud dari penelitian ini adalah melakukan analisa debit banjir dan tinggi muka air banjir pada Sungai Ciliwung STA 7+646 s/d STA 15+049 dengan menggunakan program HEC-RAS 4.1.0. Adapun tujuan dari penelitian ini adalah untuk mengetahui lokasi luapan permukaan sungai/banjir yang terjadi di ruas-ruas sepanjang Sungai Ciliwung STA 7+646 s/d STA 15+049 yaitu terletak di daerah Bidara Cina sampai Rawajati.

\section{Landasan Teori}

\subsection{Analisis Hidrologi}

Perhitungan curah hujan wilayah berdasarkan pencatatan data curah hujan stasiun hujan yang ada pada DAS Sungai Ciliwung dengan menggunakan Metode Poligon Thiessen.

\subsection{Analisis Curah Hujan Rencana}

Analisis curah hujan rencana melalui distribusi frekuensi hujan wilayah tahunan dengan 4 metode, yaitu :

Metode distribusi gumbel:

$$
\begin{aligned}
& X_{T}=\bar{X}+\left(K . S_{X}\right) \\
& K=\frac{Y_{t}-Y_{n}}{S_{n}} \\
& S=\sqrt{\frac{\sum_{i=1}^{n}\left(X_{i}-X\right)}{n-1}}
\end{aligned}
$$

Metode distribusi normal:

$$
X_{T}=X+\left(K_{T} \cdot S\right)
$$

Metode distribusi log normal:

$$
\begin{aligned}
& \log X_{T}=\log X+\left(K_{T} \cdot S \log X\right)[5] \\
& S \log X=\sqrt{\frac{\sum_{i=1}^{n}\left(\log X_{i}-\log X\right)^{2}}{n-1}}
\end{aligned}
$$

Metode distribusi log pearson type III:

$$
\begin{aligned}
& \log X_{T}=\log \bar{X}+\left(K_{T} \cdot S \log X\right) \text { [7] } \\
& C_{S}=\frac{\sum_{i=1}^{n}\left(\log X_{i}-\overline{\log X}\right)^{3}}{(n-1)(n-2)(S \log X)^{3}} \\
& S \log X=\sqrt{\frac{\sum_{i=1}^{n}\left(\log X_{i}-\log X\right)^{2}}{n-1}}
\end{aligned}
$$

\subsection{Uji Kesesuaian Distribusi Frekuensi}

Uji kesesuaian distribusi frekuensi untuk mengetahui kecocokan analisis curah hujan rencana terhadap simpangan data vertical dan horizontal dengan uji kecocokan Chi-Square dan uji kecocokan Smirnov-Kolmogorof, sehingga diketahui distribusi yang dipilih dapat diterima atau tidak berdasarkan nilai simpangan terkecil.

\subsection{Distribusi Hujan Jam-Jaman}

Analisis distribusi curah hujan rencana jamjaman setiap periode ulang guna mendapatkan curah hujan efektif yang digunakan dalam analisis debit banjir rencana. Penelitian ini menggunakan pola distribusi hujan Tadashi Tanimoto. Model Tadashi Tanimoto adalah model yang dikembangkan berdasarkan distribusi hujan yang ada di pulau Jawa dengan menggunakan lama hujan 8 (delapan) jam.

\subsection{Analisis Debit Banjir Rencana}

Analisis debit banjir rencana untuk menghitung debit/hidrograf banjir rencana berdasarkan curah hujan rencana setiap periode ulang dengan Metode Hidrograf Satuan Sintetik (HSS) Nakayasu dan HSS Gama I.

\section{HSS Nakayasu}

Waktu keterlambatan (time lag, $t_{g}$ )

Untuk L > $15 \mathrm{~km}$

$$
t_{g}=0,4+0,058 \times L
$$

Untuk L $<15 \mathrm{~km}$

$$
t_{g}=0,21 \times L^{0.7}
$$


Waktu puncak dan debit puncak HSS

$$
t_{p}=t_{g}+0,8 T_{r}
$$

Waktu puncak dan debit puncak HSS debit sama dengan 0,3 kali debit puncak

$$
t_{0.3}=\alpha \times t_{g}
$$

Debit puncak hidrograf satuan sintetis

$$
Q_{p}=\frac{1}{3,6} \times A \times R_{0} \times \frac{1}{\left(0,3 \times t_{p}+t_{0,3}\right)}
$$

\section{HSS Gama I}

Waktu Naik $\left(T_{r}\right)$

$\mathrm{T}_{\mathrm{r}}=0,43 \times \frac{\mathrm{L}^{3}}{100 \times \mathrm{SF}}+1,0665 \times \mathrm{SIM}+1,2775$

Debit Puncak $\left(Q_{P}\right)$

$\mathrm{Q}_{\mathrm{P}}=0,1836 \times \mathrm{A}^{0,5886} \times \mathrm{T}_{\mathrm{r}}^{-0,4008} \times \mathrm{JN}^{0.2381}$

Waktu Dasar $\left(T_{b}\right)$

$\mathrm{T}_{\mathrm{b}}=27,4132 \times \mathrm{T}_{\mathrm{r}}^{0,1457} \times \mathrm{S}^{-0,0986} \times \mathrm{SN}^{-0,7344} \times \mathrm{RUA}^{0,2574}$

Koefisien tampungan $(\mathrm{K})$

$\mathrm{K}=0,561 \times \mathrm{A}^{0,1793} \times \mathrm{S}^{-0,1446} \times \mathrm{SF}^{-1,0897} \times \mathrm{D}^{0,0452}$

Debit bagian turun hidrograf $\left(Q_{t}\right)$

$$
Q_{t}=Q_{P} \times e^{\left(-\frac{t}{K}\right)}
$$

\subsection{Analisis Hidrolika}

Analisis hidraulik sungai, untuk mengetahui kapasitas tampung sungai dan profil muka air banjir dengan menggunakan HEC-RAS. Data-data yang harus dimasukkan kedalam program HEC-RAS yaitu:

1. Skema Sungai

2. Data Long, Cross Section sungai

3. Angka Manning / Kekasaran

4. Debit banjir rencana

\section{Metodologi Penelitian}

Metode penelitian dimulai dengan melakukan studi literatur dengan mengkaji dan mempelajari buku-buku yang terkait dengan judul penelitian, jurnal ilmiah, penelitian terdahulu dan fasilitas internet lainnya yang berkaitan dengan tujuan dari penelitian. Kemudian dilanjutkan dengan pekerjaan lapangan yang meliputi: survei lokasi penelitian, pemilihan lokasi penelitian, dan persiapan alat dan material.

Penelitian ini dilakukan di wilayah Sungai Ciliwung khususnya pada STA $7+646$ s/d STA 15+049, yaitu terletak di daerah Bidara Cina sampai Rawajati.
Pada penelitian ini dilakukan beberapa hal yang menjadi ruang lingkup penelitian sebagai berikut :

1. Menggunakan metode Unsteady Flow analysis.

2. Kalibrasi model dengan data AWLR (Automatic Water Level Recorder).

3. Melakukan analisis statistik hujan rencana.

4. Melakukan analisis debit banjir rencana.

5. Melakukan analisis hidraulik sungai dengan simulasi model HEC-RAS 4.1.0.

6. Sungai Ciliwung yang di tinjau hanya pada STA 7+646 s/d STA 15+049.

\section{Analisis Dan Pembahasan}

\subsection{Analisis Hidrologi}

\section{Curah hujan rata-rata DAS}

Data curah hujan harian maksimum yang digunakan dalam analisis ini bersumber dari periode pencatatan 2014-2016. Berdasarkan Metode Thiessen, stasiun hujan yang berpengaruh pada DAS Sungai Ciliwung dari hulu sampai STA 7+646 ini yaitu Stasiun Cawang dan Stasiun Depok UI. Berikut merupakan luas pengaruh tiap stasiun :

\begin{tabular}{|c|c|c|c|c|c|c|}
\hline \multicolumn{7}{|c|}{ Perhitungan Hujan Harian Rata-Rata } \\
\hline \multirow[t]{2}{*}{ No } & Thn & \multicolumn{2}{|c|}{ Cawang } & \multicolumn{2}{|c|}{ Depok UI } & \multirow[t]{2}{*}{$\begin{array}{c}\begin{array}{c}\text { Jumlah cr } \\
(\mathrm{mm})\end{array}\end{array}$} \\
\hline & & RI & CRI & RI & CRI & \\
\hline 1 & 2014 & 151.5 & 11.250 & 145 & 134.233 & 145.483 \\
\hline 2 & 2015 & 130 & 9.653 & 117 & 108.312 & 117.965 \\
\hline 3 & 2016 & 146 & 10.841 & 137 & 126.827 & 137.668 \\
\hline \multicolumn{4}{|c|}{ tata } & & & 133.705 \\
\hline
\end{tabular}

Tabel 1. Luas Pengaruh Stasiun Hujan

\begin{tabular}{|c|c|c|c|}
\hline \multicolumn{4}{|c|}{ Perhitungan Hujan Harian Rata-Rata Metode Thiessen } \\
\hline No & $\begin{array}{c}\text { Nama } \\
\text { Stasiun }\end{array}$ & $\begin{array}{c}\text { Luas (Ai) } \\
\left(\mathbf{K m}^{2}\right)\end{array}$ & $\begin{array}{c}\text { Koef.Thiessen } \\
(\mathbf{c})(\%)\end{array}$ \\
\hline 1 & Cawang & 24.161 & 7.426 \\
\hline 2 & Depok UI & 301.21 & 92.574 \\
\hline Total & & 325.371 & 100 \\
\hline
\end{tabular}

Tabel 2. Hujan Harian Rata-rata

\section{Analisis curah hujan rencana}

Metode distribusi probabilitas yang digunakan untuk menghitung hujan rencana atau debit rencana, seperti Gumbel, Normal, Log Normal, Log Pearson Tipe III. Hasil analisis dengan ke empat metode tersebut, kemudian diujikan kesesuaian distribusinya dengan menggunakan dua metode yaitu Chi Square dan Smirnov-Kolmogorof.

Hasil dari kedua pengujian kesesuaian distribusi dapat dilihat pada tabel berikut. 
Tabel 3. Rekapitulasi Hasil Uji Chi Square

\begin{tabular}{|l|c|c|c|}
\hline \multicolumn{4}{|c|}{ Rekapitulasi Nilai $\mathbf{X}^{\mathbf{2}}$ dan $\mathbf{X}^{2} \mathbf{c}_{\mathbf{r}}$} \\
\hline \multicolumn{1}{|c|}{ Nama } & $\begin{array}{c}\mathbf{X}^{\mathbf{2}} \\
\text { Terhitung }\end{array}$ & $\mathbf{X}^{2} \mathbf{c}_{\mathbf{r}}$ & Keterangan \\
\hline Gumbel & 1.00 & 3.35 & Diterima \\
\hline Log Normal & 1.00 & 3.35 & Diterima \\
\hline Normal & 1.00 & 3.35 & Diterima \\
\hline $\begin{array}{l}\text { Log Pearson } \\
\text { Type 3 }\end{array}$ & 3.00 & 3.35 & Diterima \\
\hline
\end{tabular}

Untuk metode Smirnov-Kolmogorof seperti terlampir pada tabel berikut.

Tabel 4. Rekapitulasi Hasil Uji Smirnov-Kolmogorof

\begin{tabular}{|l|c|c|c|}
\hline \multicolumn{3}{|c|}{ Rekapitulasi Nilai $\Delta \mathbf{P}$ Maksimum dan $\Delta \mathbf{P}$ Kritis } \\
\hline DistribusiProbabilitas & $\begin{array}{c}\Delta \mathrm{P} \\
\text { Maks }\end{array}$ & \multirow{2}{*}{$\Delta$ P Kritis } & Keterangan \\
\hline Gumbel & 0.306 & & Diterima \\
\hline Log Normal & 0.368 & \multirow{2}{*}{0.591} & Diterima \\
\hline Log Pearson Type 3 & 0.301 & & Diterima \\
\hline Normal & 0.360 & & Diterima \\
\hline
\end{tabular}

Dari hasil perhitungan uji Chi-Square diatas menunjukan bahwa semua distribusi probabilitas memiliki nila $X^{2}<X_{C R}^{2}$ maka dapat disimpulkan bahwa semua distribusi tersebut dapat diterima.

Selanjutnya akan diadakan satu pengujian lagi diantara sebaran distribusi yang lolos yaitu uji Smirnov-Kolmogorof.

Dari hasil pengujian Smirnov-Kolmogorov semua distribusi probabilitas memiliki nilai $\Delta \mathrm{P}$ maks $<\Delta$ P kritis maka dapat disimpulkan bahwa semua distribusi tersebut dapat diterima. Namun untuk menghitung debit banjir rencana dipakai distribusi Gumbel.

\section{Distribusi hujan jam-jaman}

Dalam analisa perhitungan debit banjir rencana dalam memperkirakan besaran debit diperlukan data curah hujan maksimum jam-jaman serta curah hujan efektif. Berikut merupakan pola distribusi hujan Tadashi Tanimoto:

Tabel 5 Distribusi Hujan Tadashi Tanimoto

\begin{tabular}{lcccccccc}
\hline $\begin{array}{l}\text { Waktu } \\
\text { (jam ke-) }\end{array}$ & 1 & 2 & 3 & 4 & 5 & 6 & 7 & 8 \\
\hline \hline$\%$ & 26 & 24 & 17 & 13 & 7 & 5.5 & 4 & 3.5 \\
$\begin{array}{l}\text { Distribusi } \\
\text { hujan } \\
\%\end{array}$ & & & & & & & & \\
$\begin{array}{l}\text { Distribusi } \\
\text { hujan } \\
\text { kumulatif }\end{array}$ & 26 & 50 & 67 & 80 & 87 & 92.5 & 96.5 & 100 \\
\hline
\end{tabular}

\subsection{Analisis Debit Banjir Rencana}

\section{HSS Nakayasu}

Berdasarkan hasil perhitungan, debit maksimum dari metode Hydrograf Satuan Nakayasu setiap periode ulang adalah sebagai berikut:

Tabel 6. Rekapitulasi Debit Banjir Rencana HSS Nakayasu

\begin{tabular}{|c|c|}
\hline \multicolumn{2}{|c|}{$\begin{array}{c}\text { Debit puncak banjir rencana HSS Nakayasu untuk } \\
\text { periode ulang tahun }\end{array}$} \\
\hline $\begin{array}{c}\text { Periode ulang } \\
\text { (tahun) }\end{array}$ & Debit puncak banjir rencana $\left(\mathrm{m}^{3} / \mathrm{det}\right)$ \\
\hline 5 & 687.80 \\
\hline 10 & 743.21 \\
\hline 20 & 796.36 \\
\hline 50 & 865.15 \\
\hline 100 & 916.71 \\
\hline
\end{tabular}

Hidrograf debit banjir rencana HSS Nakayasu dengan berbagai periode ulang dapat dilihat pada gambar 1 .

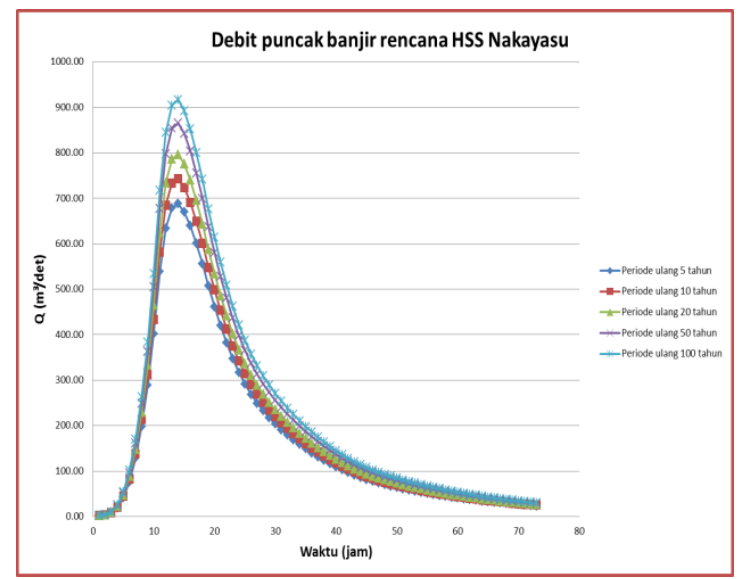

Gambar 1 Debit Puncak Banjir Rencana HSS Nakayasu

Berdasarkan hasil perhitungan, debit maksimum dari metode Hidrograf Satuan Gama I setiap periode ulang sebagai berikut :

Tabel 7. Rekapitulasi Debit Banjir Rencana HSS Gama I

\begin{tabular}{|c|c|}
\hline \multicolumn{2}{|c|}{$\begin{array}{c}\text { Debit puncak banjir rencana HSS Gama 1 untuk } \\
\text { periode ulang tahun }\end{array}$} \\
\hline Periode ulang (tahun) & Debit banjir rencana (m²/det) \\
\hline 5 & 347.03 \\
\hline 10 & 372.12 \\
\hline 20 & 396.20 \\
\hline 50 & 427.36 \\
\hline 100 & 450.71 \\
\hline
\end{tabular}

Hidrograf debit banjir rencana HSS Gama I dengan berbagai periode ulang dapat dilihat pada gambar 2 . 


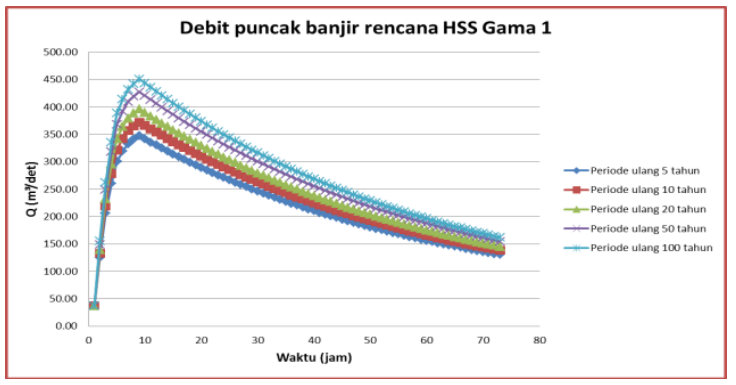

Gambar 2 Debit Puncak Banjir Rencana HSS Gama 1

\subsection{Kalibrasi}

Untuk mendapatkan hasil kalibrasi, maka dilakukan survey lapangan untuk mengukur kecepatan sesaat di penampang Sungai Ciliwung pada STA yang ditinjau. Berdasarkan hasil survei tersebut diperoleh kecepatan rata-rata yaitu sebesar $1,242 \mathrm{~m} /$ det. Sehingga didapatkan debit sebesar :

$\mathrm{Q}=\mathrm{A}^{\prime} \times \mathrm{V}=264,538 \times 1,242=328,556 \mathrm{~m}^{3} /$ det.

Debit puncak banjir rencana Sungai Ciliwung dari hulu sampai hilir manggarai berdasarkan perhitungan HSS Nakayasu yaitu didapat sebesar $660,95 \mathrm{~m}^{3} /$ det. Berdasarkan hasil perhitungan debit banjir rencana dengan HSS Nakayasu diasumsikan yang paling mendekati nilai dari debit berdasarkan data AWLR yang terletak di pintu air Manggarai. Meskipun ada perbedaan besaran debit, hal ini bisa terjadi mengingat adanya percabangan sungai yang terletak di Manggarai yang lebarnya hampir sama dengan lebar sungai utama Sungai Ciliwung dan tidak memperhitungkan outflow.

\subsection{Analisis Hidrolika}

Analisa hidraulik Sungai Ciliwung dengan menggunakan pemodelan HEC-RAS, dilakukan untuk mendapatkan kapasitas saluran yang diperlukan untuk membantu mengatasi masalah banjir di kawasan Sungai Ciliwung STA 7+646 s/d STA $15+049$.

\section{Skematik Pemodelan} berikut:

Bentuk skematik dapat dilihat pada gambar 3

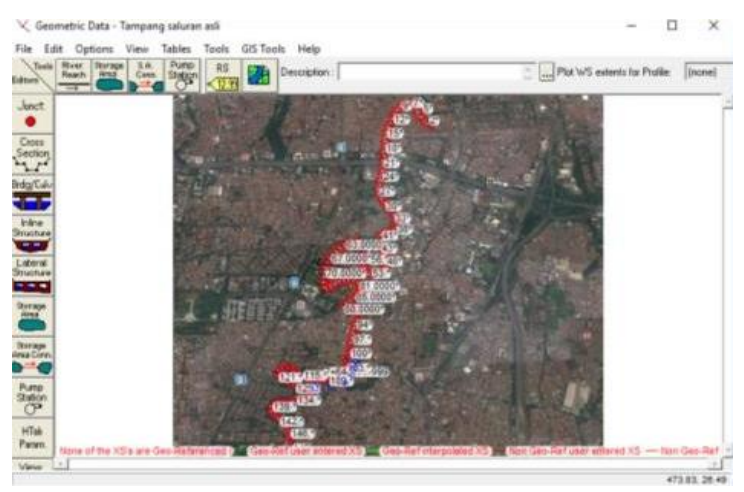

Gambar 3 Skematik Pemodelan

\section{Data Geometrik}

Contoh input data potongan melintang dapat dilihat pada gambar berikut:

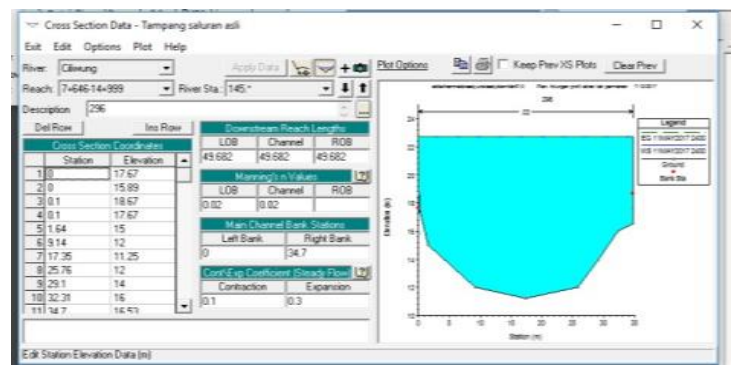

Gambar 4 Contoh Input Data Potongan Melintang

\section{Flow Boundary Condition/Syarat Batas}

Besarnya debit yang direncanakan akan berlaku sebagai boundary condition dalam pemodelan ini. Besaran debit dimodelkan sebagai debit inflow maupun lateral yang masuk kedalam kali/saluran. Langkah berikutnya yang dapat dilakukan setelah memasukkan seluruh data geometri sungai adalah memasukkan kondisi aliran sungai apakah aliran tetap (Steady Flow) maupun kondisi aliran tidak tetap (Unsteady Flow). Pada analisa ini dilakukan dengan unsteady flow analysis. Kemudian akan dimasukan nilai flow hydrograph dan stage hydrograph, dimana nilai flow hydrograph didapatkan dari hasil perhitungan debit banjir rencana metode Nakayasu.

\section{Analisa Hidraulik Kondisi Eksisting Sungai Ciliwung}

Analisis kapasitas penampang eksisting Sungai Ciliwung dilakukan pada kondisi sungai yang ada saat ini dengan tujuan untuk mengetahui kapasitas pengaliran maksimum pada masing-masing segmen sungai. Berikut ini adalah hasil analisa kondisi Sungai Ciliwung, yang dapat dilihat pada gambar berikut ini:

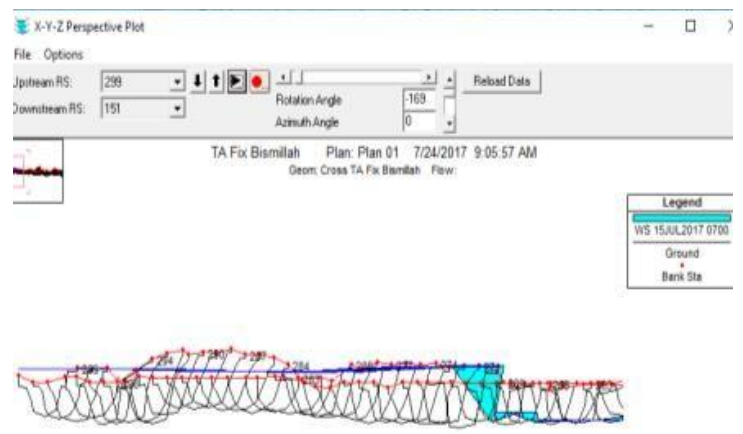

Gambar 5 Geometrik Penampang Sungai Ciliwung 
Pemodelan HEC-RAS Sungai Ciliwung dengan debit rencana 5 tahun.

Berdasarkan hasil running dengan debit rencana periode ulang 5 tahun diatas menunjukan bahwa, mulai terjadi banjir pada tanggal 15 Juli 2017 pada pukul 07:00 yaitu pada potongan 299 sampai dengan potongan 269 (STA 15+049 s/d STA 13+548) yang terletak didaerah Rawajati, dengan debit $198.11 \mathrm{~m}^{3} /$ det. Hasil pemodelan HECRAS dengan debit rencana periode ulang 5 tahun menunjukan bahwa terdapat beberapa stasioning telah mengalami genangan banjir. Stasioning yang mengalami banjir yaitu sampai potongan 222 yang terletak didaerah Rawajati sampai dengan Pengadegan Timur.

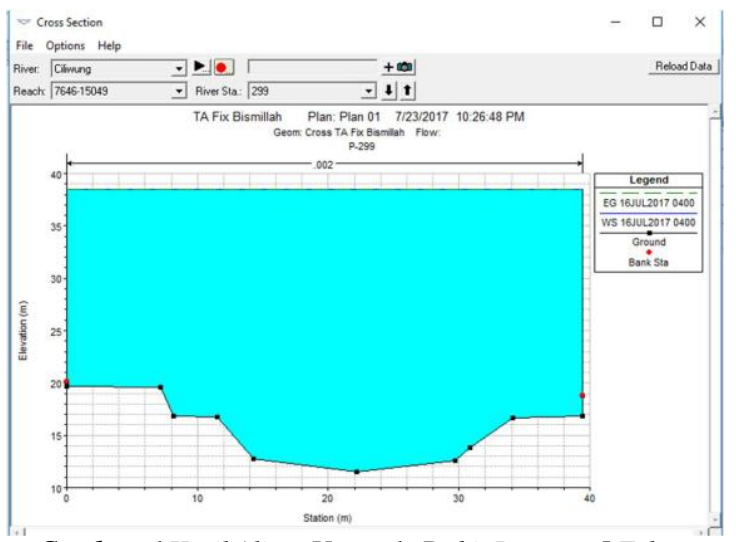

Gambar 6 Hasil Aliran Unsteady Debit Rencana 5 Tahun pada Potongan 299

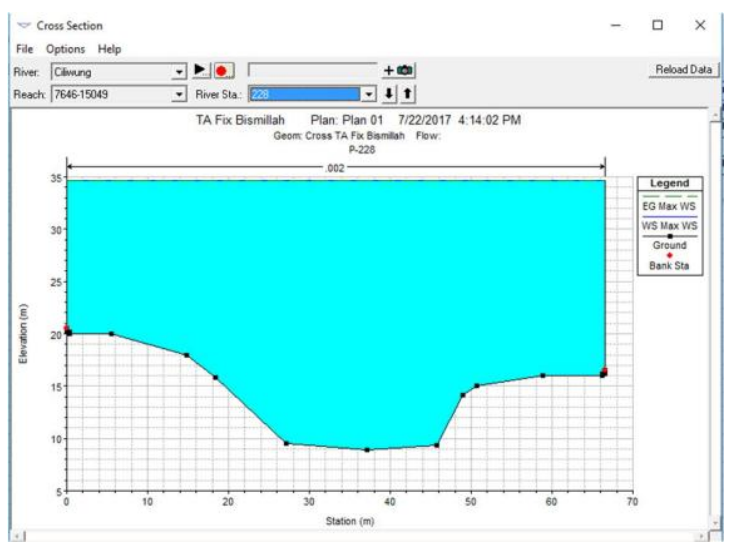

Gambar 7 Hasil Aliran Unsteady Debit Rencana 5 Tahun pada Potongan 228

Pemodelan HEC-RAS Sungai Ciliwung dengan debit rencana 10 tahun.

Hasil running dengan debit rencana periode ulang 10 tahun menunjukan mulai terjadi banjir pada tanggal 15 Juli 2017 pada pukul 07:00 yaitu pada potongan 299 sampai dengan potongan 286 (STA 15+049 s/d STA 13+99) yang terletak didaerah Rawajati, dengan debit $213.9 \mathrm{~m}^{3} /$ det. Hasil pemodelan HEC-RAS dengan debit rencana periode ulang 10 tahun menunjukan bahwa terdapat beberapa stasioning telah mengalami genangan banjir. Stasioning yang mengalami banjir yaitu sampai potongan 227 yang terletak di daerah Rawajati sampai dengan Pengadegan.

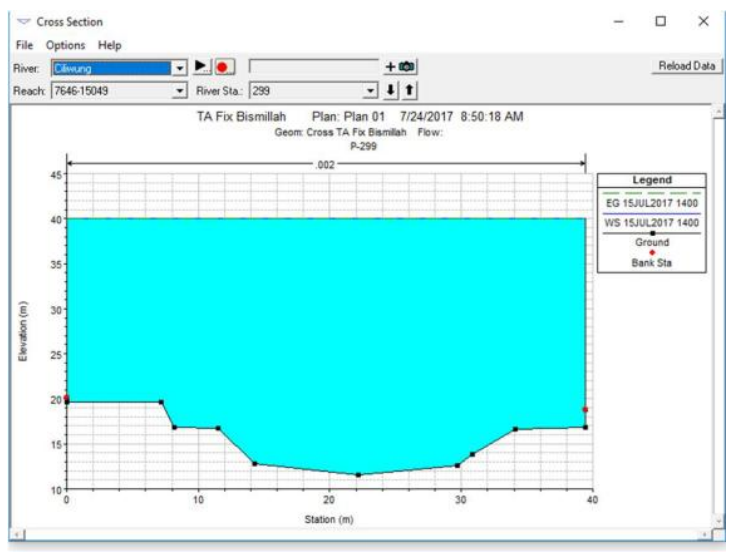

Gambar 8 Hasil Aliran Unsteady Debit Rencana 10 Tahun pada Potongan 299

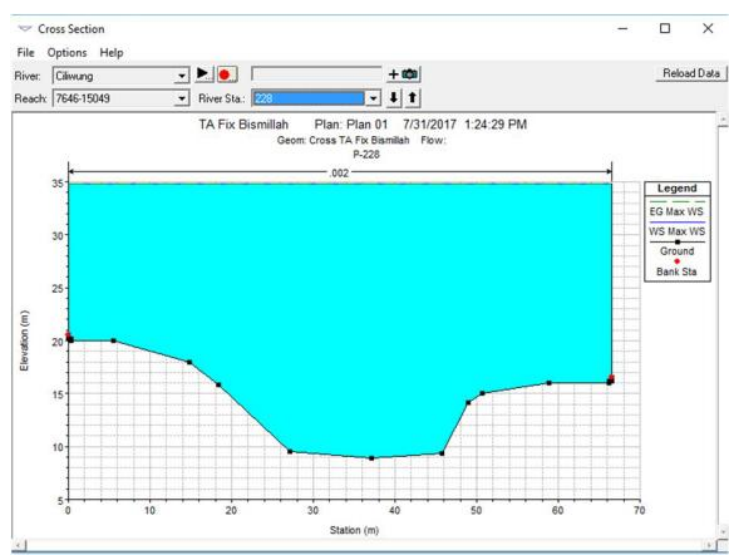

Gambar 9 Hasil Aliran Unsteady Debit Rencana 10 Tahun pada Potongan 228

Pemodelan HEC-RAS Sungai Ciliwung dengan debit rencana 20 tahun.

Hasil running dengan debit rencana periode ulang 20 tahun menunjukan mulai terjadi banjir pada tanggal 15 Juli 2017 pada pukul 04:00 yaitu pada potongan 299 sampai dengan potongan 282 (STA 15+049 s/d STA 14+199) yang terletak didaerah Rawajati, dengan debit $47.84 \mathrm{~m}^{3} /$ det. Hasil pemodelan HEC-RAS dengan debit rencana periode ulang 20 tahun menunjukan bahwa hampir seluruh stasioning telah mengalami genangan banjir. Stasioning yang mengalami banjir yaitu sampai potongan 183 yang terletak didaerah Rawajati sampai dengan Cawang. 


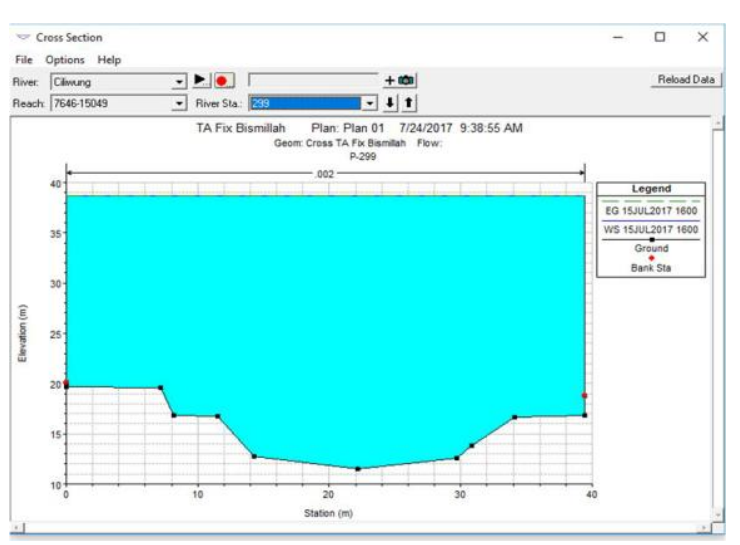

Gambar 10 Hasil Aliran Unsteady Debit Rencana 20 Tahun pada Potongan 299

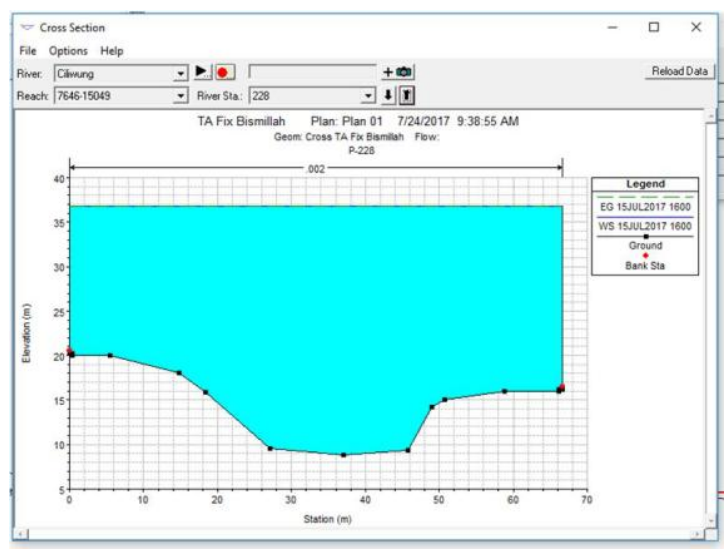

Gambar 11 Hasil Aliran Unsteady Debit Rencana 20 Tahun pada Potongan 228

Dari hasil pemodelan HEC-RAS Sungai Ciliwung dengan beberapa periode ulang diatas, banjir mulai menggenangi sebagian besar stasioning pada debit rencana periode ulang 20 tahun yaitu pada STA 15+049 s/d STA 9+297 yang terletak di daerah Rawajati hingga Cawang. Maka dari itu harus dilakukan perubahan alur sungai dengan melakukan penanggulan.

\section{Kesimpulan}

Dari uraian pembahasan dapat disimpulkan sebagai berikut:

1. Berdasarkan hasil kalibrasi dan perhitungan debit banjir rencana dengan metode HSS Nakayasu dan HSS Gama I, maka untuk angka debit yang diinput pada software HEC-RAS 4.1.0 adalah hasil dari perhitungan Metode HSS Nakayasu hal ini dikarenakan nilai debit yang mendekati nilai AWLR dan juga merupakan nilai debit terbesar, sehingga dianggap dalam kondisi yang kritis.
2. Debit puncak banjir Sungai Ciliwung $\begin{array}{llll}\text { STA } & 7+646 \quad \text { s/d } & \text { STA } & 15+049\end{array}$

Berdasarkan HSS Nakayasu :

$>$ periode ulang 5 tahun $(\mathrm{Q} 5)=$ $687,80 \mathrm{~m}^{3} / \mathrm{dt}$

$>$ periode ulang 10 tahun $(\mathrm{Q} 10)=$ $743,21 \mathrm{~m}^{3} / \mathrm{dt}$

$>$ periode ulang 20 tahun $(\mathrm{Q} 20)=$ $796,36 \mathrm{~m}^{3} / \mathrm{dt}$

$>$ periode ulang 50 tahun $(\mathrm{Q} 50)=$ $865,15 \mathrm{~m}^{3} / \mathrm{dt}$

periode ulang 100 tahun $(\mathrm{Q} 100)=$ $916,71 \mathrm{~m}^{3} / \mathrm{dt}$

3. Berdasarkan hasil pemodelan HEC- RAS 4.1.0, Sebagian besar stationing Sungai Ciliwung pada STA 7+646 s/d STA 15+049 tidak dapat menampung debit rencana pada periode ulang 20 tahun.

4. Berdasarkan studi yang telah dilakukan, diketahui bahwa luapan air di Sungai Ciliwung terjadi karena adanya debit banjir yang besar dari hulu, tanpa disertai upaya pengendalian. Sehingga diperlukan upaya pengendalian banjir yaitu perbaikan sungai berupa normalisasi sungai dan peninggian tanggul.

\section{Daftar Pustaka}

[1] Awan Darmawan, Farouk Maricar, dan Riswal Karamma. 2015. Analisis Hidrograf Sungai dengan Menggunakan HSS di Daerah Aliran Sungai Saddang Kabupaten Pinrang.

[2] Harahap Rumilla, Nasution Zulkifli, Rauf Abdul, dan Mawengkang Herman. 2015. Hydrology Model for Determination on the Flood Index Based Analysis of Flood Discharge for Asahan River Management. International Research Journal of Engineering and Technology (IRJET), Volume 2 Issue : 07

[3] Kamiana, I Made. 2010. Teknik Perhitungan Debit Rencana Bangunan Air. Yogyakarta: Graha Ilmu.

[4] Nugraha. M Agung. 2014. Analisis Hidrograf Banjir Pada DAS Boang. Jurnal Teknik Sipil dan Lingkungan, Volume 2 No 4. 2016

[5] Rahman, Kahfi Aulia. 2014. HEC-RAS (River Analysis System).

[6] Rapar Sharon Marthina Esther, Eveline M Tiny Mananoma, Wuisan, dan Binilang Alex. 2014. Analisis Debit Banjir Sungai Tondano Menggunakan Metode HSS Gama I dan HSS Limantara. Jurnal Sipil Statik, Volume 2 No 1.

[7] http://ejournal.unsrat.ac.id/index.php/j Wigati Restu, Soedarsono, dan Mutia Tia. 2016. Analisis Banjir Menggunakan Software HEC-RAS 4.1.0 (Studi Kasus Sub-DAS Ciberang HM O+OO - HM 34+00). Jurnal Fondasi, Volume 5 No 2. 